\title{
Transformational leadership and the European Foundation for Quality Management model in five-star hotels
}

Silvia Portela Maquieira

University of Alicante, Alicante, Spain, and

Juan José Tarí and José F. Molina-Azorín

Department of Business Management, University of Alicante, Alicante, Spain

\begin{abstract}
Purpose - This work analyses quality management (through the European Foundation for Quality Management-EFQM-model) and transformational leadership in hotels in Spain.

Design/methodology/approach - The study analyses 102 5-star and 5-star large luxury hotels that answer a questionnaire on transformational leadership and the EFQM model. It analyses the degree of importance of quality and transformational leadership in hotels, the significant differences between groups of hotels (according to stars, size, modality and type of product) and the association between transformational leadership and quality.
\end{abstract}

Findings - The results show the levels of quality and transformational leadership, minor significant differences between groups and an association between the two variables. In general, chain-affiliated hotels have a higher level of leadership and a more advanced employee and process management than independent hotels. Also, those hotels that focus on a vacational product show a lower attention to the strategy dimension in the EFQM model. The number of employees is not an important factor to adopt quality. Finally, transformational leadership allows hotels to advance in the development of quality management.

Originality/value - Although there are studies on quality management that show the importance of leadership for quality, there are few studies that examine transformational leadership and quality in the same study, mainly in the tourism industry, and especially in the case of the hotel industry.

Keywords Transformational leadership, EFQM model, Quality management, Five-star hotels

Paper type Research paper

(C) Silvia Portela Maquieira, Juan José Tarí and José F Molina-Azorín. Published in Journal of Tourism Analysis: Revista de Análisis Turístico. Published by Emerald Publishing Limited. This article is published under the Creative Commons Attribution (CC BY 4.0) licence. Anyone may reproduce, distribute, translate and create derivative works of this article (for both commercial and non-commercial purposes), subject to full attribution to the original publication and authors. The full terms of this licence may be seen at http://creativecommons.org/licences/by/4.0/ legalcode 
JTA

27,2

100

\section{Introduction}

Leadership is a key element for developing a quality culture (Koc, 2006; Pereira-Moliner et al., 2012; Wang et al., 2012), and transformational leadership is the most appropriate type of leadership to adopt quality management practices in a successful way (Dean and Bowen, 1994; Waldman, 1994; Yee et al., 2013). This is because of the fact that transformational leadership has been associated with the success of organizations to a higher extent than other leadership styles and because it facilitates quality commitment, employee motivation (Masi and Cooke, 2000), improved relationships between followers and leaders, improved effectiveness of teams, improved work processes and employee satisfaction (Brown et al., 1996; Guillespie and Mann, 2000; Avolio and Bass, 2004). Although there are studies in tourism on transformational leadership (Jovicic et al., 2018) and on quality management (Liu and Ko, 2018), there are few works that analyze quality management and transformational leadership in the same study, mainly in the tourism industry and, especially, in the case of the hotel industry.

The tourism industry in Spain is the main engine of the Spanish economy. The contribution to the Spanish GDP of the tourism activities is 11.2 per cent, and it creates 2.6 million jobs and 13 per cent of total employment [Instituto Nacional de Estadística (INE), 2016]. The positive balance of tourism amounted to 3.5 per cent of GDP in 2017 (Bank of Spain - Banco de España, 2018). During 2017, 81.8 million international tourists visited Spain, which is 8.6 per cent more than the previous year [Instituto Nacional de Estadística (INE), 2018].

The aim of this study is to analyze the level of implementation of transformational leadership and quality management and the association between the two variables in Spanish five-star hotels. For that purpose, the work analyzes the importance of transformational leadership and quality, the existence of differences regarding these issues between groups of hotels and the association between the two variables.

\section{Literature review}

\subsection{Transformational leadership}

A transformational leader identifies the needs of his/her followers and motivates them (Burns, 1978), encouraging them to go beyond their own personal interests for the benefit of the entire group (Miles and Huberman, 1994). Yukl (1999) defines a transformational leader as a leader that develops actions that empower his/her followers and makes them involved in the way to attain organizational goals, by using different behaviors according to the situation (advice, support, intellectual stimulation, etc.). Based on this prior research, the definition of transformational leadership for this work can be considered as follows: transformational leadership is the art of influencing and driving people by encouraging them to work in an enthusiastic way toward a common goal. Transformational leadership is composed of four dimensions according to the literature (Avolio and Bass, 2004; Laohavichien et al., 2011; Lee et al., 2011), which will be considered for this research:

(1) Idealized influence. This dimension has two perspectives:

- As a personal attribute: the leader is charismatic and is perceived by the followers as a person with great ethics and integrity.

- As a behavior: it considers that the leader heads the problem-solving process and shares the success with his/her followers.

(2) Intellectual stimulation. The leader makes his/her followers think by themselves and develop their own skills. 
(3) Inspirational motivation. The leader encourages his/her followers to achieve a higher performance and attains an extra effort from them.

(4) Individualized consideration. The leader is a good communicator and listens to his/ her followers, because he/she shows empathy with them.

\subsection{Quality management}

Quality management is a business management system that organizations can develop.

Model in fivestar hotels Companies can use different models to adopt quality management such as, amongst others, the European Foundation for Quality Management (EFQM) model and the ISO 9001 standard. The EFQM model is a quality model that reflects the quality management principles suggested by the literature and is a tool for management allowing them to measure the satisfaction of customers, employees and other stakeholders (Black and Crumley, 1997; Larsen and Häversjö, 2001; Pérez, 1998; Abella, 1998; Gómez et al., 2015; Liu and Ko, 2018; Simancas Cruz et al., 2018).

For the success of this model, the involvement of employees and top management is required. This model is composed of nine dimensions (see Figure 1) that show quality management dimensions suggested by the literature. Also, this model can be successfully adopted by tourism organizations in general and hotels in particular (Wang et al., 2012; Álvarez-García et al., 2016).

\subsection{Leadership in the European Foundation for Quality Management model}

According to the EFQM model, quality management requires that leaders adapt, react and gain commitment with all stakeholders to ensure the success of the organization (EFQM, 2010a). In the EFQM model, leadership contributes to achieve the strategy, to understand what is important to do as a leader and to develop a quality culture where excellence is the standard (EFQM, 2010b). The leader has to act as a model in its implementation (Sandbrook, 2001).

According to EFQM (2013) model, excellent organizations have leaders that shape the future and make it happen, acting as role models of their values and ethical principles and inspiring confidence at all times. They are flexible, allowing the organization to anticipate and react in a timely way to ensure continuous success. The dimension leadership of the $\mathrm{EFQM}$ model has five subcriteria related to mission, improvement, external stakeholders and excellence culture (Table I).

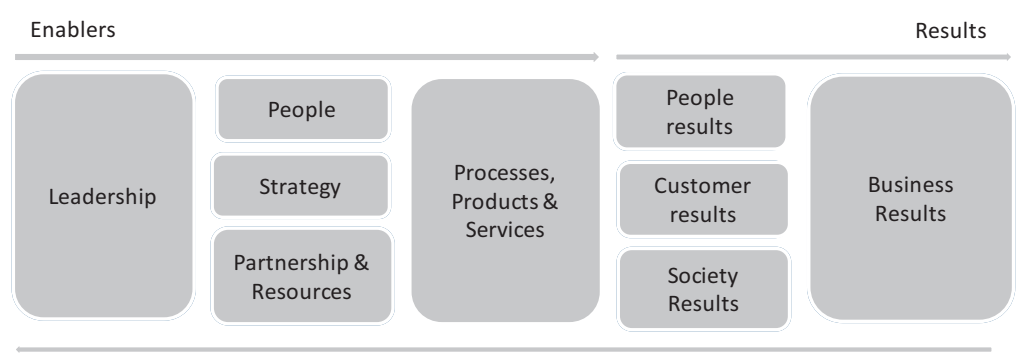

Learning, Creativity and Innovation

Figure 1. EFQM model

Source: EFQM (2013) 
JTA

27,2

102

Issues related to vision and values, continuous improvement through employees and change management are typical of leadership according to the EFQM model and of transformational leadership. This suggests similarities between the characteristics of transformational leadership and appropriate leadership in the EFQM model. This idea suggests that an association may exist between transformational leadership and the EFQM model.

Regarding the adoption of quality management in organizations, some works show that large organizations are used to having more resources to apply certain practices such as those related to quality (Sun and Cheng, 2002; Diaz de Cerio, 2003; Haar and Spell, 2008). Nevertheless, other studies find that there are no differences in the degree of development of quality management according to size (Powell, 1995; Ghobadian and Gallerar, 1996; Zu et al., 2008; Berrios and Campos, 2016). This shows that both large and small hotels could develop quality management successfully. This discussion in the literature also exists in relation to other organizational variables. For example, in general terms, some works show that the hotels with a higher category (Abrate et al., 2011; Orfila-Sintes et al., 2005) and size (Mak, 2011; Iglesias et al., 2018) can adopt quality initiatives to a higher extent than those hotels with lower category and size. Similarly, relationships may exist between the adoption of quality practices and nonurban hotels (Iglesias et al., 2018). Although prior literature shows inconclusive results, it can be said that some differences in the development of quality and leadership can exist according to organizational characteristics. This idea makes it possible to propose the following hypothesis:

H1. Significant differences exist between the level of development of transformational leadership and quality management according to organizational characteristics (category, modality, type of product and size).

Regarding the association between transformational leadership and quality practices, the literature shows that leadership is a key factor to develop quality management and the enablers of EFQM (Table II). The literature also shows the positive effects of transformational leadership on employees, as well as the fact that certain characteristics of leaders are needed for quality improvement and the success of organizations. In this regard, some works show the importance of transformational leadership to develop quality and continuous improvement (Table II). These ideas make it possible to propose the following hypothesis:

H2. An association exists between transformational leadership and quality.

Table I.

Subcriteria in the leadership criterion in the EFQM model

\begin{tabular}{|c|c|}
\hline Criteria & Subcriterion \\
\hline Leadership & $\begin{array}{l}\text { Leaders develop mission, vision, values and ethical principles and act as a reference model } \\
\text { Leaders define, monitor, review and drive both the improvement of the organization's } \\
\text { management system and its performance } \\
\text { Leaders engage with external stakeholders } \\
\text { Leaders reinforce an excellence culture among the people in the organization } \\
\text { Leaders ensure organization is flexible and manages change effectively }\end{array}$ \\
\hline
\end{tabular}

Source: $\mathrm{EFQM}(2013)$ 


\section{Authors}

Main results

Waldman (1994)

Pheng and May (1997)

Eskildsen and Dahlgaard (2000)

Podsakoff et al. (2000)

Lebracher et al. (2002)

Soltani et al. (2004)

Yeung et al. (2005)

Fisher et al. (2005)

Osseo-Asare et al. (2005)

Calvo-Mora et al. (2005)

Davies (2008)

Hai Chin and An Lin (2009)

Castro et al. (2009)

Laohavichien et al. (2011)

Álvarez-García et al. (2012)

Kara et al. (2013)

Mendoza et al. (2014)

Doeleman et al. (2014)

Yosia (2015)

Álvarez-García et al. (2016)

Source: Portela (2016) management learning
Leadership needed for an effective quality management program is transformational leadership

Leadership style plays an important role in quality management. The ideal manager must meet the following characteristics: have a high position, good interpersonal relationships, understand the operations of the company, etc. Leadership affects people, strategy and partnerships and resources

Transformational leadership increases employee satisfaction and the organizational environment

Top management commitment and initiative, under the transformational leadership of the CEO, is essential to build and maintain a continuous improvement program

Leadership encourages employee participation in quality improvement in companies applying the EFQM model

The person responsible for managing quality in the company must be on the first hierarchical line, as well as exercise leadership within his/her team Leadership is essential to establish a continuous improvement program or quality management, along with cooperative learning and process

Leadership is one of the success factors in quality and performance improvement as long as it is included in the company's policy and strategy. Effective leadership clearly involves communicating the mission, the vision and fundamental values

Leadership has a positive influence on people management Leadership has a clear effect on the effectiveness of model application, on promoting the use of various levels of the model and its use in strategic planning and performance

There is a strong and positive relationship between leadership style, quality management and organizational commitment

Leadership is shown as one of the important variables of the EFQM model and has a decisive influence on enablers of the EFQM model

Transformational leadership makes it easier for employees to exceed the minimum levels required by the organization. Therefore, a transformational leader is likely to influence the company's quality results by implementing quality practices

Leadership influences customer results, people results, society results and business results

Transformational leadership has positive effects in the hospitality sector. This means that managers must be trained to use a transformational leadership style to improve employee well-being

Transformational leadership develops the potential in followers and improves the team's values and motivation. This type of leadership motivates followers to work together, change their goals and beliefs and look beyond their personal interests to achieve organizational interests

Leadership is a driver of quality improvement and is needed for an effective EFQM model implementation

Transformational leadership has positive effects on performance. The interpersonal skills of leaders and sincerity impact on quality management Leadership impacts on partnerships and resources, strategy, employees and
Model in fivestar hotels

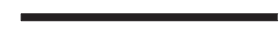




\subsection{Population and sample}

The hotel industry is a critical sector for the Spanish economy, as has been indicated in the introductory section. According to the Spanish National Institute of Statistics [Instituto Nacional de Estadística (INE), 2016], the number of five-star hotels increased by 20.8 per cent during the 2008-2014 period. However, the rest of categories have suffered a generalized decrease. This is because of the increase in tourism quality in Spain. For example, five-star hotels have showed a growth of 27 per cent in the average stay during the 2008-2014 period [Instituto Nacional de Estadística (INE), 2016]. This group of hotels offers a service with a higher quality level compared with lower category hotels and they are hotels that have improved their results during the past years of economic crisis. Profitability data of these hotels support these ideas. In addition, previous works focus on the analysis of hotels of different categories and there is a lack of studies focused on this group of hotels (five-star hotels).

These data show the importance of five-star hotels within the hotel industry in Spain. Also, there are few works that analyze the relationship between transformational leadership and quality management in the hotel industry, and more specifically in five-star hotels.

Thus, the population are five-star hotels and five large luxury star hotels, because they are hotels that can offer a service with a high level of quality and can have higher profitability compared to establishments with lower categories. Based on this idea, a database according to information available in the Turespaña website (Turespaña, 2015) was created: a census of 162 five-star hotels and five large luxury star hotels. A structured questionnaire with closed questions was sent online to these hotels in three waves, between January and March 2016. A total of 102 answers were received.

\subsection{Measures}

The questionnaire begins with general questions to identify a profile of the establishments:

- category;

- number of rooms;

- modality of the establishment (chain-affiliated hotel or independent hotel);

- type of tourist product that the hotel offers (vacational, urban or mixed); and

- number of employees last year.

In addition, the questionnaire shows questions on transformational leadership and quality management that the quality manager or person with a quality responsibility, or failing this, the top manager, answers on the leadership style in the hotel and the importance of enablers and results of the EFQM model. Managers answered the questionnaire using a five-point scale $(1=$ totally disagree; $5=$ totally agree). To measure transformational leadership, four dimensions and 12 items are used (see Table III) based on Laohavichien et al. (2011) and Lee et al. (2011). To measure quality management, 16 items (see Table IV) are considered based on Bou-Llusar et al. (2009) and Gómez et al. (2015). To analyze the impact of enablers of EFQM on performance, 18 items are used (see Table V) based on Pereira-Moliner et al. (2016). As these variables are perceptual, reliability and validity analyses are performed as shown in Tables III-V. 


\begin{tabular}{|c|c|c|c|}
\hline & Mean & Factor & $\begin{array}{l}\text { in nive- } \\
\text { - hotels }\end{array}$ \\
\hline $\begin{array}{l}\text { Idealized influence } \\
\text { 1. Engages employees in his/her future vision } \\
\text { 2. Expresses his/her their most important values and beliefs to employees } \\
\text { 3. Inspires loyalty to the establishment in employees } \\
\text { Eigenvalue per factor } \\
\text { \% of variance explained } \\
\text { Kaiser-Meyer-Olkin index } \\
\text { Barlett's significance test of sphericity } \\
\text { Cronbach's alpha }\end{array}$ & $\begin{array}{l}4.37 \\
4.29 \\
4.40 \\
4.43\end{array}$ & $\begin{array}{r}0.911 \\
0.797 \\
0.841 \\
2.173 \\
72.426 \\
0.650 \\
0.000 \\
0.809\end{array}$ & 105 \\
\hline $\begin{array}{l}\text { Inspirational motivation } \\
\text { 1. There is a strong communicative culture in all areas of the establishment } \\
\text { 2. His/her behavior allows the integration and mobilization of teams } \\
\text { 3. They are consistent between what they say and what they do } \\
\text { Eigenvalue per factor } \\
\text { \% of variance explained } \\
\text { Kaiser-Meyer-Olkin index } \\
\text { Barlett's significance test of sphericity } \\
\text { Cronbach's alpha }\end{array}$ & $\begin{array}{l}4.32 \\
4.18 \\
4.44 \\
4.34\end{array}$ & $\begin{array}{r}0.844 \\
0.853 \\
0.815 \\
2.104 \\
70.126 \\
0.701 \\
0.000 \\
0.785\end{array}$ & \\
\hline $\begin{array}{l}\text { Individualized consideration } \\
\text { 1. Takes into account the personal feelings of his/her employees before acting } \\
\text { 2. Encourages employees to think about the best way to do things } \\
\text { 3. Shows employees the benefits of achieving establishment goals } \\
\text { Eigenvalue per factor } \\
\% \text { of variance explained } \\
\text { Kaiser-Meyer-Olkin index } \\
\text { Barlett's significance test of sphericity } \\
\text { Cronbach's alpha }\end{array}$ & $\begin{array}{l}4.30 \\
4.21 \\
4.41 \\
4.30\end{array}$ & $\begin{array}{r}0.845 \\
0.793 \\
0.881 \\
2.119 \\
70.634 \\
0.681 \\
0.000 \\
0.792\end{array}$ & \\
\hline $\begin{array}{l}\text { Intellectual stimulation } \\
\text { 1. Takes part in continuous improvement processes, even when these } \\
\text { activities go beyond management responsibilities } \\
\text { 2. Interested in knowing the needs of his/her working group } \\
\text { 3. Allows employees to think about old problems in new ways } \\
\text { Eigenvalue per factor } \\
\% \text { of variance explained } \\
\text { Kaiser-Meyer-Olkin index } \\
\text { Barlett's significance test of sphericity } \\
\text { Cronbach's alpha }\end{array}$ & $\begin{array}{l}4.17 \\
4.33 \\
4.30\end{array}$ & $\begin{array}{c}0.876 \\
0.825 \\
0.853 \\
2.174 \\
72.467 \\
0.705 \\
0.000 \\
8.808\end{array}$ & $\begin{array}{r}\text { Table III. } \\
\text { Items on } \\
\text { transformational } \\
\text { leadership (reliability } \\
\text { and validity) }\end{array}$ \\
\hline
\end{tabular}

\section{Results}

\subsection{Descriptive analyses}

Most establishments (51 per cent) have between 1 and 100 rooms. In the other extreme, there are hotels with more than 400 rooms (3 per cent). A total of 24 per cent of hotels have between 101 and 200 rooms, 14 per cent between 201 and 300 rooms and 9 per cent between 301 and 400 .

Regarding the modality, 52 per cent of the hotels belong to a chain and 48 per cent are independent hotels. In relation to the type of product that the establishments provide, 42 per cent offer a vacational product, 22 per cent an urban product and 36 per cent a mixed product (urban and vacational). Finally, regarding number of employees, 27 per cent are small hotels (between 10 and 49 employees), 60 per cent are medium-sized hotels (50 and 250 employees) and 7 per cent are large ones (more than 250 employees). 
Strategy

4.39

1. Sets objectives taking into account the opinions and needs of customers, employees and other stakeholders (society, shareholders)

2. Informs employees about quality strategies

3. Reviews the effectiveness of his/her strategies and plans

4.33

0.933

Eigenvalue per factor

2.532

$\%$ of variance explained

84.402

Kaiser-Meyer-Olkin index

0.749

Barlett's significance test of sphericity

0.000

Cronbach's alpha

0.907

People

4.30

1. Encourages employee autonomy and participation

2. Encourages and supports individual and team participation in improvement activities

3. Develops training and development programs for employees

4. Uses formal processes to understand employee feedback and improve staff policies

5. Explicitly acknowledges to employees their involvement and assumption of

responsibilities

Eigenvalue per factor

$\%$ of variance explained

Kaiser-Meyer-Olkin index

Barlett's significance test of sphericity

0.869

Cronbach's alpha

Partnership and resources

\section{Has a high capacity for external cooperation}

0.859

2. Identifies opportunities to build partnerships with other organizations

3. Establishes quality agreements with suppliers

0.880

4. Facilitates access to information for all those who need to know it

0.809

Eigenvalue per factor

0.870

2.924

$\%$ of variance explained

Kaiser-Meyer-Olkin index

Barlett's significance test of sphericity

Cronbach's alpha

Processes, products and services

1. Explicitly defines working methods and processes

2. Implements process indicators and performance targets

3. Identifies and prioritizes opportunities for continuous improvement

4. Designs, develops, produces and offers products and services based on

\subsection{Transformational leadership}

In the case of transformational leadership, Table III shows that "Idealized influence" is the most important dimension of leadership (4.37). The second most valued dimension is "Inspirational motivation." The least important dimension is "Intellectual stimulation." 


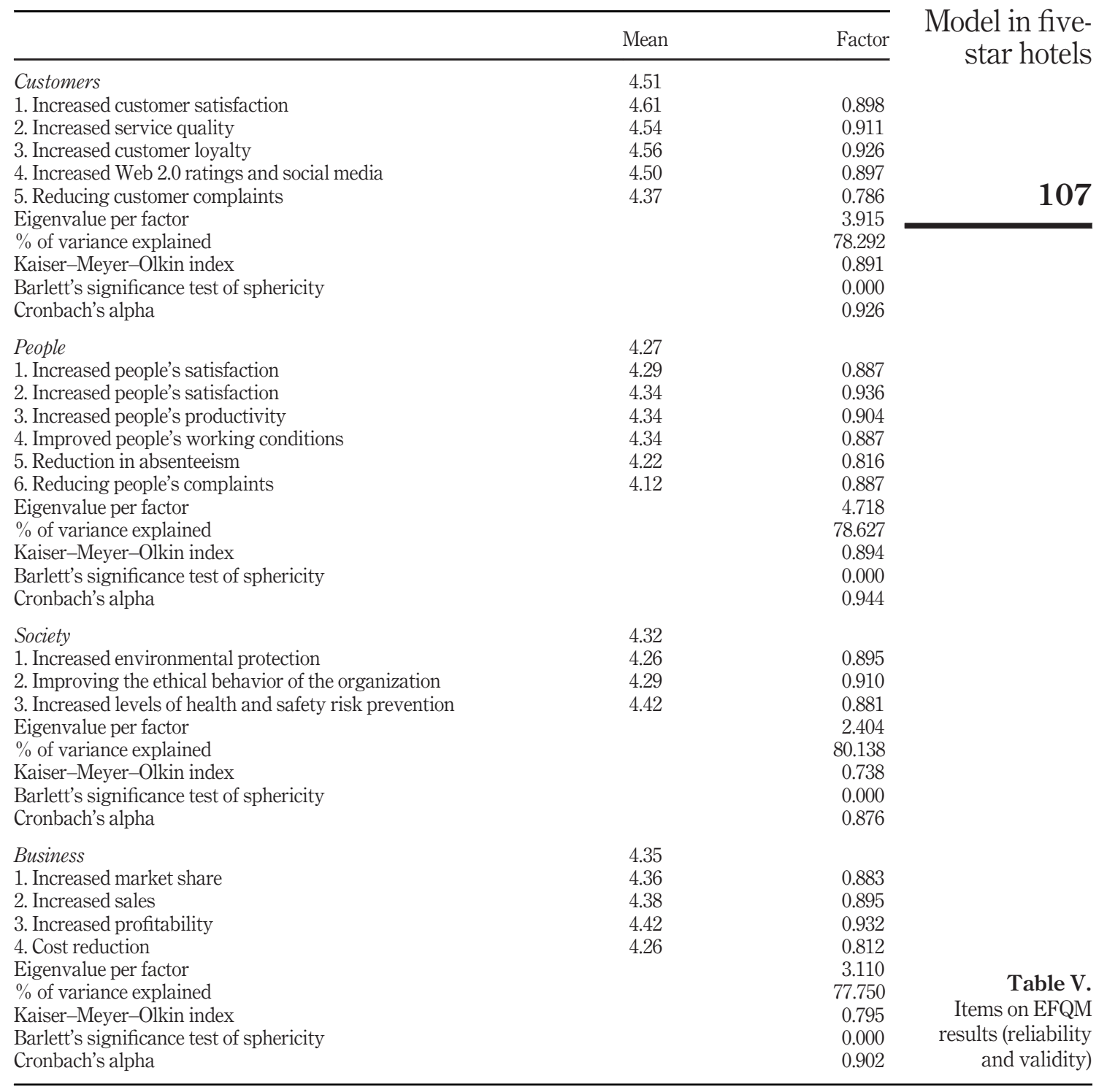

Nevertheless, there are very little differences between dimensions (see Table III), which indicates that the level of transformation leadership is high in the hotels analyzed.

Table III also shows the results (means) of each item. These results show that leaders allow the integration and the mobilization of their followers (4.44) and inspire employee loyalty to the establishment (4.43). On the contrary, the two aspects of leadership least developed in hotels and, therefore, the behaviors to improve are the following: "taking part in the processes of continuous improvement, even when these 
activities go beyond their responsibilities" and "there is a strong communicative culture in all areas of the hotel."

\subsection{European Foundation for Quality Management enablers}

The results show that the most important dimension or enabler with a mean of 4.39 is "Strategy" (Table IV) and the least valued enabler is "Partnership and resources" (4.12). Regarding the quality management practices developed by the hotels, the most important is

"establishing objectives taking into account opinions and needs of customers, employees and other stakeholders (e.g. society)" (4.47). This indicates that leaders understand needs and expectations of the stakeholders and the environment to define strategy (Table IV). On the contrary, the least implemented quality practices are as follows: "hotels identify the opportunities to establish alliances with other organizations," "hotels use formal processes to know employee opinions and improve employee policies" and "hotel establishes quality agreements with suppliers." Thus, the improvement areas in hotels are related to the lack of high external cooperation and to the need to improve communication with employees (see Table IV).

\subsection{European Foundation for Quality Management results}

Table $\mathrm{V}$ shows the means regarding the result dimensions. The most important impact is on customers (4.51), and the least important is on employees (4.27). This indicates that quality has somehow clearer effects on increased customer satisfaction, increased service quality, increased customer loyalty, increased assessments in Web 2.0 and social networks and the reduction in customer complaints. Similarly, the effects are somehow lower on employees: increased employee satisfaction, increased employee motivation, increased employee productivity, improved work conditions, reduction in absenteeism and complaints. These results also show that quality management practices can also have positive effects on society results (environmental protection, organizational ethics and prevention of labor risks) and on business results such as market share, sales and costs.

Table V also shows that the most important impacts are "increased customer satisfaction" (mean of 4.61) and "increased customer loyalty" (4.56). On the contrary, the least valued impact is that related to human resources variables. This indicates that quality practices have clear benefits in the improvement of customer satisfaction and, although improvements in employees also exist, they are lower.

\subsection{Significant differences and association between leadership and quality}

This section supplements the previous one with an analysis of significant differences of the variables measured between groups of hotels and a regression analysis between the two variables. In relation to category, there are no significant differences regarding enablers of EFQM (strategy, people, alliances and processes) and regarding customer, employee and social results and business results between five-star hotels and five-star large luxury hotels. As Table VI shows, minor differences can be observed between two dimensions of transformational leadership $(\phi<0.10)$.

This indicates that similarities exist between communicative culture, the commitment and leader behavior, as well as the consistency between their words and their acts. In addition, leaders in both types of establishments behave in such a way that they allow the integration and the mobilization of the members of their teams. Also, it can be said that both five-star and five large luxury star hotel leaders take into account the feelings of their followers, express their gratitude when employees do a good job and show them the benefits of achieving organizational goals. Regarding "Intellectual stimulation," in both types of 


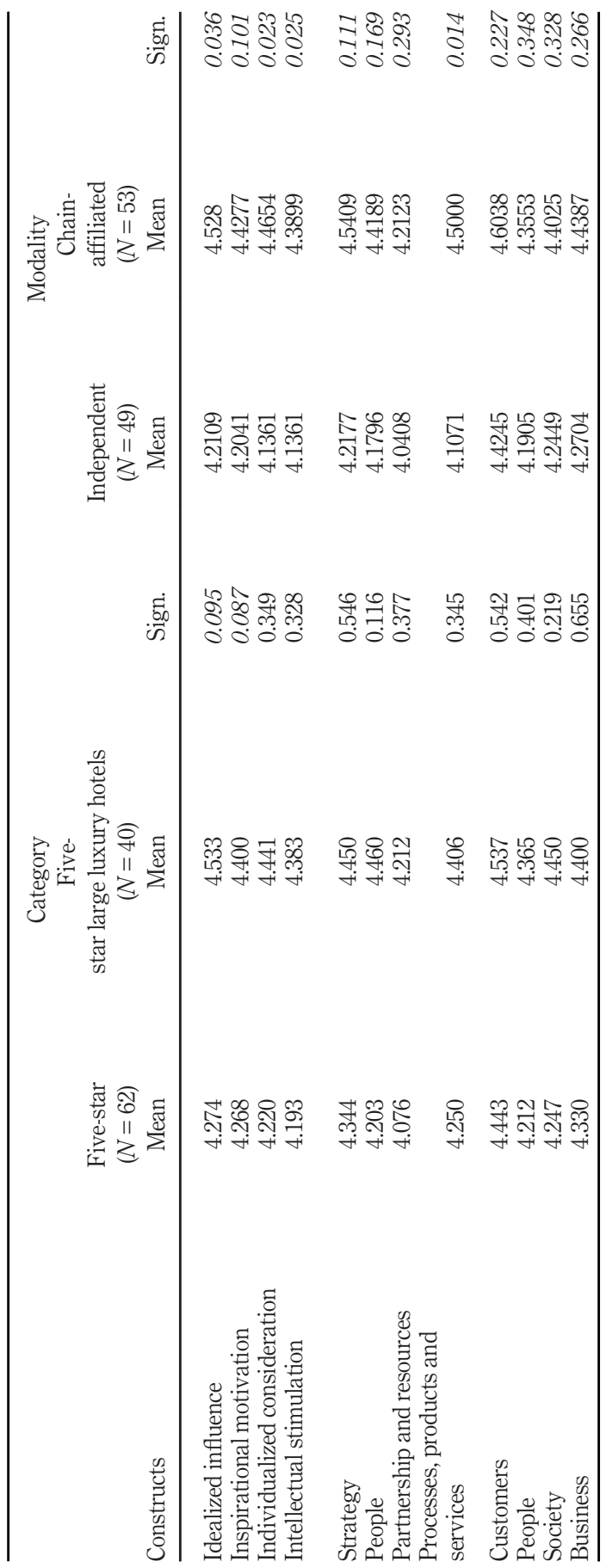

Model in fivestar hotels and differences regarding category and modality 
hotels, many similarities exist between leaders when they work in groups, take part in the processes of continuous improvement and understand employee needs.

Five-star and five-star large luxury hotels have a similar level of implementation of strategy dimensions. In general terms, both types of hotels establish objectives and collect internal and external data, and communicate and review their strategy with a similar level of development. Both five-star and five-star large luxury hotels develop training programs for employees and encourage their autonomy and their individual participation in improvement activities. Regarding "Partnership and resources," both types of hotels cooperate with external organizations and identify the opportunities to establish alliances with other organizations. In addition, they establish agreements with suppliers and facilitate access to the information to all those that have to know it. Both kinds of hotels have a similar level of implementation of process indicators, so that, in general, both types of hotels design, develop, produce and offer products and services based on customer needs with a similar level of development. Finally, the effects of enablers on customer, employee, society and business results are also similar in both types of hotels.

Regarding the modality (see Table VI), significant differences exist in relation to dimensions "Idealized influence," "Individualized consideration" and "Intellectual stimulation" between independent hotels and chain-affiliated hotels. Similarly, there are also differences in the dimension "Processes, products and services" $(p<0.05)$. Consequently, chain-affiliated hotels develop these dimensions to a higher extent.

Table VII shows the differences by type of product and by number of employees, and Table VIII shows the differences regarding the number of rooms.

Regarding the type of product that the hotel offers (urban, vacational or mixed), there is some difference in the dimension strategy $(p<0.10)$. It seems that vacational hotels pay less attention to the definition and control of objectives. Concerning number of employees, results indicate that number of employees is not an important factor to develop both leadership and quality practices to a higher or lower extent. Nevertheless, in the cases where there are small groups, the non-parametric test is also applied ( $\mathrm{H}$ of Kruskal-Wallis). In these cases, results show that some differences can exist in dimensions people and processes $(p<0.10)$, indicating that size could be a factor that might have some influence in people and process management. Similarly, hotels with more rooms have a higher level of the dimension "Inspirational motivation" and develop the dimensions "People management" and "Product, process and services" to a higher extent.

Regarding the association between leadership and quality, regression analysis shows that transformational leadership facilitates quality development. A significant relationship exists $(\phi<0.05)$ between:

- idealized influence, inspirational motivation and intellectual stimulation with strategy and people management;

- intellectual stimulation and alliances; and

- the four dimensions of transformational leadership and process management.

These results partially support $H 1$, because certain significant differences between groups of hotels exist. Similarly, $H 2$ is partially supported because a relationship exists between the two variables, although not all dimensions of transformational leadership impact on all enablers of EFQM. 


\section{Conclusions}

The present research shows data that shed light toward a better knowledge of transformational leadership and quality management in five-star hotels. These hotels integrate the dimension "Idealized influence" of transformational leadership in their activities, which refers to the charismatic actions of leaders that focus on values, beliefs and the sense of mission (Lee et al., 2011). Leaders are admired by their followers, as they are a role model for their values and ethical behavior. The results show that leaders engage their employees in their future vision, express their values and beliefs to employees and inspire in

Model in fivestar hotels them loyalty to the company.

In addition, it can be highlighted that transformational leadership impacts on quality management (EFQM enablers). That is, through idealized influence, inspirational motivation and intellectual stimulation, transformational leadership influences strategy, people management and process management. Through vision and values, communication and employee motivation and the promotion of creativity and continuous improvement, leaders can develop planning processes, improve relationships with employees and boost analysis and work process improvement. These characteristics related to communication, people relationships, creativity and solving problems, which are important for the improvement of enablers of EFQM, are critical for the leaders of hotels, as prior research has found regarding the key competences of leaders in the hotel industry (Kay and Moncarz, 2007; Jeou-Shyan et al., 2011; Bharwani and Talib, 2017). Similarly, intellectual stimulation influences alliances and individual consideration in process improvement; for example, taking into account employees' needs is important so that they feel involved in process improvement. These results support previous authors' works that show the importance of these competences in transformational leadership to improve in hotels (Jovicic et al., 2018) and other works applied to other contexts other than hotels that have found a relationship between transformational leadership and quality (Teoman and Ulengin, 2018). Also, these results expand previous works that show the relationship between leadership and enablers of EFQM in the tourism industry (Álvarez-García et al., 2016), expanding these results to the case of transformational leadership.

Regarding quality practices, in general terms, leaders of both types of hotels take into account the feelings of their employees, express their gratitude when these employees do a good job and show them the benefits of achieving organizational goals.

Nevertheless, some differences can be suggested in the development of transformational leadership and quality. Regarding the modality of the establishment, chain-affiliated hotels have a higher level of transformational leadership than independent hotels and have more advanced people management and process management. In relation to the type of tourism product that the hotels offer, it can be said that minor differences exist in strategy in vacational hotels, in this case with the lowest implementation level. The hotels focused on a vacational product pay lower attention to the dimension strategy. Finally, number of employees is not an important factor in the implementation of quality management, although it seems that large hotels give more importance to people management and process management. Based on these results, the following improvement areas for hotels can be suggested:

- Hotels that wish to improve their level of quality management have to define vision and values and work on this idea until it becomes a reality. In this regard, it is important that leaders also make efforts to communicate, motivate and apply practices for continuous improvement. In this case, one of the least valued items in leadership is the item related to participation in continuous improvement. Taking 
JTA

27,2

112

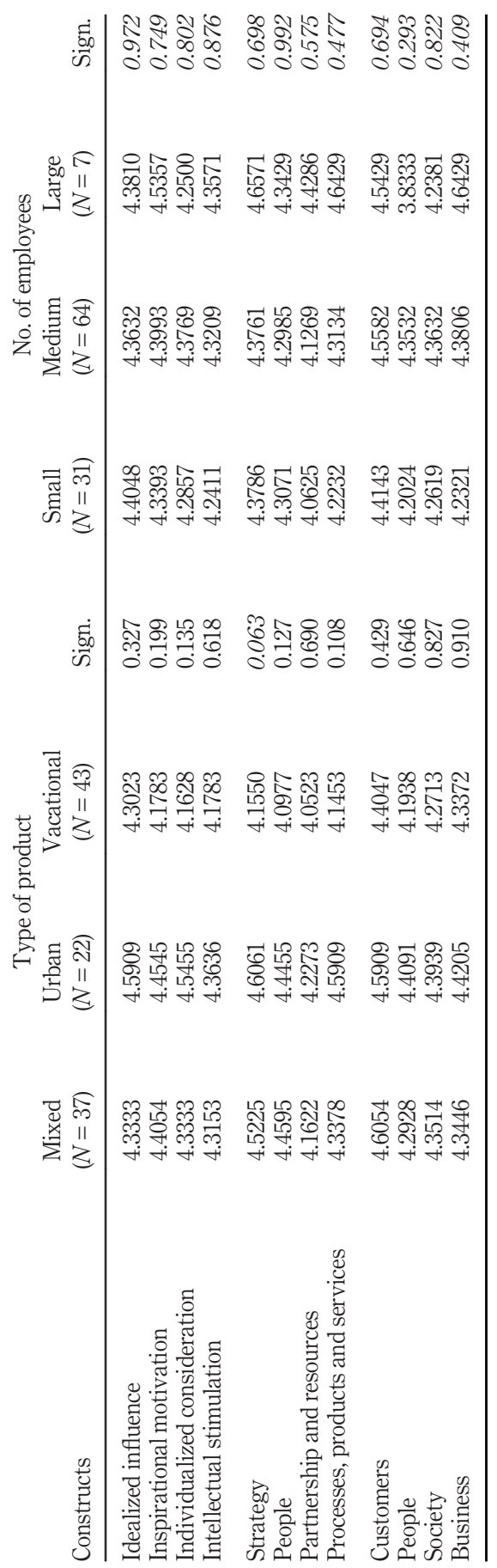

Table VII.

Descriptive analysis and differences regarding type of product and number of employees 


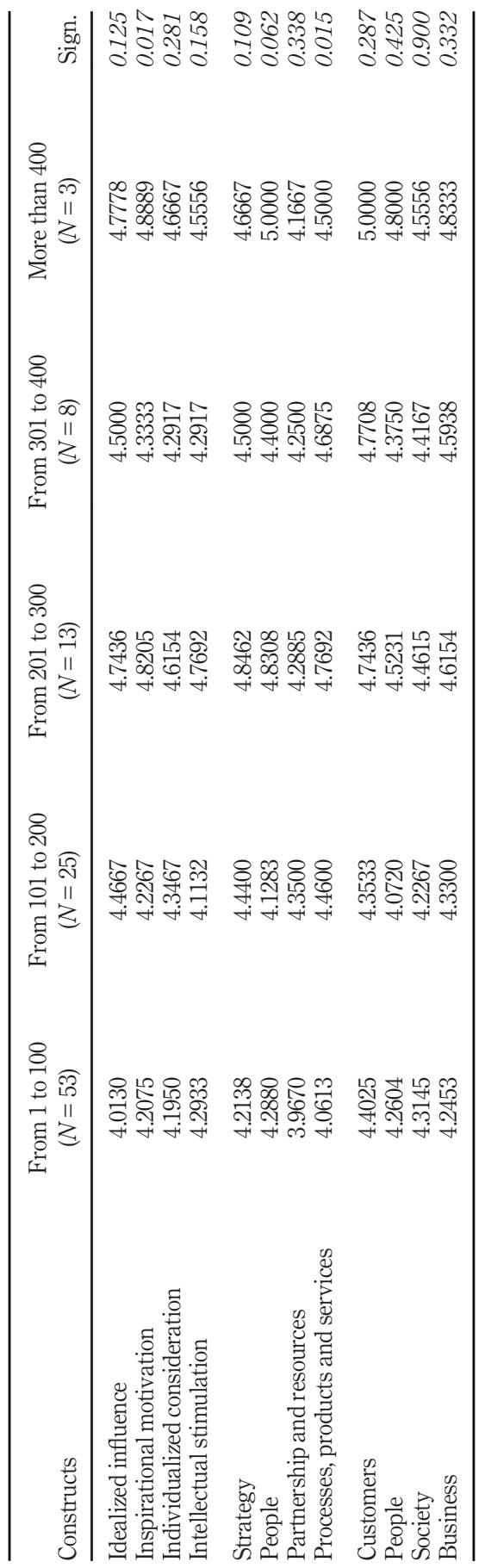

Model in fivestar hotels

Table VIII.

Descriptive analysis and differences regarding number of rooms 
into account these weaknesses and the fact that the characteristics related to intellectual stimulation are important for quality improvement, a higher commitment to continuous improvement activities with the participation of employees will make them improve the quality practices adopted in the hotel. In addition, the dimension "Intellectual stimulation" is one of the least important ones; therefore, leaders should obtain their stakeholders' opinions to identify strategies and process in the search for continuous improvement.

- Managers in hotels have to act as role models both because of their values and principles and because of their performance. They have to inspire confidence and loyalty in other people, because one of the least valued items is related to communicative culture in all areas of the establishment.

- Managers in hotels have to be conscious of the importance of communication, the relationship with employees, creativity, critical thought and strategic thought because they also are key competences for a successful behavior of hotel managers (Kay and Moncarz, 2007; Jeou-Shyan et al., 2011; Bharwani and Talib, 2017).

Regarding enablers of EFQM, the following suggestions to improve quality management in hotels can be made:

- Leaders should strengthen the relationship with stakeholders and partners. It is recommended that managers extend their leadership to the whole value chain, that is, to both employees and external collaborators, such as suppliers, as a way of improving their work processes.

Concerning EFQM results, the suggestions are the following:

- The issues that have obtained a lower value are related with employee results. Taking into account the association between leadership and people management, managers should interact more with employees by participating in improvement activities and transparently recognizing staff efforts and improvements by employees.

\section{Limitations and future research}

This work presents interesting results on transformational leadership and quality management in hotels. Nevertheless, it has some limitations. The work has collected the information in a moment of time. Thus, it would be interesting in the future to carry out a longitudinal study to know the level of transformational leadership and quality, and the effects of this leadership on quality management.

In addition, this study has used data from 102 hotels and collected the information of one person per hotel. It would be interesting in the future to expand the sample to several respondents, for example, managers and employees, and to hotels in other categories, or even to other tourism subsectors or other services .

\section{References}

Abella, A. (1998), "El modelo europeo para PYME y su relación con las prácticas empresariales", Alta Dirección, Vol. 197, pp. 25-32.

Abrate, G., Capriello, A. and Fraquelli, G. (2011), "When quality signals talk: evidence from the Turin hotel industry”, Tourism Management, Vol. 32 No. 4, pp. 912-921. 
Álvarez-García, J., Fraiz Brea, J.A., D. and Río-Rama, M.C. (2012), "The effects of implementing Q for quality on the business performance", European Journal of Tourism Hospitality Recreation, Vol. 3, pp. 53-75.

Álvarez-García, J., Del Río-Rama, M.C., Saraiva, M. and Ramos-Pires, A. (2016), "Dependency relationships between critical factors of quality and employee satisfaction”, Total Quality Management and Business Excellence, Vol. 27, pp. 595-612.

Avolio, B. and Bass, B.M. (2004), Multifactor Leadership Questionnaire: Manual and Sampler Set, Mind Garden, Redwood City. CA.

Model in fivestar hotels

Banco de España (2018), "La balanza de pagos y la posición de inversión internacional de españa en 2017”, Boletín económico 2/2018.

Berrios, R. and Campos, S. (2016), "Calidad percibida de los servicios: una aplicación a los servicios de hospedaje en león de Nicaragua”, Revista de Análisis Turístico, Vol. 21, pp. 42-50.

Bharwani, S. and Talib, P. (2017), "Competences of hotel general managers: a conceptual framework", International Journal of Contemporary Hospitality Management, Vol. 29 No. 1, pp. 393-418.

Black, S.A. and Crumley, H.C. (1997), "Self-assessment: what's in it for us?", Total Quality Management, Vol. 8 No. 2-3, pp. 90-93.

Bou-Llusar, J., Escrig-Tena, A., Roca-Puig, V. and Beltrán-Martín, I. (2009), “An empirical assessment of the EFQM excellence model: evaluation as a TQM framework relative to the MBNQA model", Journal of Operations Management, Vol. 27 No. 1, pp. 1-22.

Brown, W., Birnstihl, E. and Wheeler, D. (1996), "Leading without authority: an examination of the impact of transformational leadership cooperative extension work groups and teams", Journal of Extension, Vol. 34, p. 5.

Burns, J.M. (1978), Leadership, Harper and Row, New York, NY.

Calvo-Mora, A., Leal, A. and Roldán, J. (2005), "Relationships between the EFQM model criteria: a study in Spanish universities", Total Quality Management and Business Excellence, Vol. 16 No. 6, pp. 741-770.

Castro, C.J., González, S.G., Guenaga, G.G. and Mijangos del Campo, J.J. (2009), "El factor liderazgo en el modelo EFQM de excelencia: análisis empírico en el país vasco", Estudios de Economía Aplicada, Vol. 1-34, pp. 27-22.

Davies, J. (2008), "Integration: is it the key to effective implementation of the EFQM excellence model?", International Journal of Quality and Reliability Management, Vol. 25, pp. 383-399.

Dean, J.W. and Bowen, D.E. (1994), "Management theory and total quality: improving research and practice through theory development", Academy of Management Review, Vol. 19 No. 3, pp. 392-418.

Diaz de Cerio, J.M. (2003), "Factors relating to the adoption of quality management practices: an analysis for Spanish manufacturing firms", Total Quality Management and Business Excellence, Vol. 14, pp. 25-44.

Doeleman, H.J., ten Have, S. and Ahaus, C.T.B. (2014), "Empirical evidence on applying the European foundation for quality management excellence model, a literature review", Total Quality Management and Business Excellence, Vol. 25, pp. 439-460.

$\operatorname{EFQM}$ (2010a), "Introducing the EFQM excellence model 2010", available at: www.efqm.org

EFQM (2010b), "Benefits of using the EFQM excellence model 2010”, available at: www.efqm.org

EFQM (2013), "Excellent organisations achieve and sustain outstanding levels of performance that meet or exceed the expectations of all their stakeholders", available at: www.efqm.org

Eskildsen, J.K. and Dahlgaard, J.J. (2000), “A casual model for employee satisfaction”, Total Quality Management, Vol. 11 No. 8, pp. 1081-1094.

Fisher, C., Barfield, J., Li, J. and Mehta, R. (2005), "Retesting a model of the deming management method", Total Quality Management and Business Excellence, Vol. 16 No. 3, pp. 401-412. 
Ghobadian, A. and Gallerar, D.N. (1996), "Total quality management in SMEs", Omega, Vol. 24, pp. 83-106.

Gómez, G.J., Martínez, C.M. and Martínez, L.A.R. (2015), “An in-depth review of the internal relationships of the EFQM model”, The TQM Journal, Vol. 27 No. 5, pp. 486-502.

Guillespie, N. and Mann, L. (2000), "The building blocks of trusts: the role of transformational leadership and shared values in predicting team members' trust in their leaders", Academy of Management Conference.

Haar, J.M. and Spell, C.S. (2008), "Predicting total quality management adoption in New Zealand: the moderating effect of organisational size", Journal of Enterprise Information Management, Vol. 21 No. 2, pp. 162-178.

Hai Chin, W. and An Lin, Y. (2009), "The study of the antecedent factors or organizational commitment for high-tech industries in Taiwan", Total Quality Management and Business Excellence, Vol. 20, pp. 799-815.

Iglesias, V., De la Ballina, F.J. and Caso, L. (2018), "Investment decisions on quality certifications by hotel chains: differences between ex-ante and ex-post decisions", Spanish Journal of Marketing ESIC, Vol. 22 No. 1, pp. 83-102.

Instituto Nacional de Estadística (INE) (2016), "Cuenta satélite del turismo de españa”, available at: www.ine.es/jaxi/menu.do?type=pcaxis\&path $=/ \mathrm{t} 35 / \mathrm{p} 011 \&$ file=inebase

Instituto Nacional de Estadística (INE) (2018), "España en cifras 2017 catálogo de publicaciones oficiales de la administración general del estado", available at: http://publicacionesoficiales. boe.es

Jeou-Shyan, H., Hsuan, H., Chih-Hsing, L., Lin, L. and Chang-Yen, T. (2011), "Competence analysis of top managers in the Taiwanese hotel industry", International Journal of Hospitality Management, Vol. 30 No. 4, pp. 1044-1054.

Jovicic, A., Damnjanovic, J., Papic-Blagojevic, N., Josanov-Vrgovic, I. and Gagic, S. (2018), "Impact of leadership on innovation: evidence from the hotel industry", Management: Journal of Sustainable Business and Management Solutions in Emerging Economies, Vol. 23, pp. 57-66.

Kara, D., Uysalb, M., Sirgyc, M.J. and Leed, G. (2013), "The effects of leadership style on employee wellbeing in hospitality", International Journal of Hospitality Management, Vol. 34, pp. 9-18.

Kay, C. and Moncarz, E. (2007), "Lodging management success: personal antecedents, achievements, KSAs and situational influencers", International Journal of Hospitality Management, Vol. 26 No. 1, pp. 33-48.

Koc, E. (2006), "Total quality management and business excellence in services: the implications of allinclusive pricing system on internal and external customer satisfaction in the Turkish tourism market”, Total Quality Management and Business Excellence, Vol. 17 No. 7, pp. 857-877.

Laohavichien, T.L., Fredendall, R.D. and Stephen, C. (2011), "Leadership and quality management practices in Thailand", International Journal of Operations and Production Management, Vol. 31, pp. 1048-1070.

Larsen, B. and Häversjö, T. (2001), "Management by standards real benefits from fashion", Scandinavian Journal of Management, Vol. 17, pp. 457-480.

Lebracher, R., Whissell, R. and Ojha, A. (2002), Organisational Learning, Transformational Leadership and Implementation of Continuous Quality Improvement in Canadian Hospitals, EBOSC Publising.

Lee, P.K.C., Cheng, T.C.E., Yeung, A.C.L. and Lai, K.H. (2011), “An empirical study of transformational leadership, team performance and service quality in retail banks”, Omega, Vol. 39 No. 6, pp. 690-701.

Liu, Y.-L. and Ko, P.-F. (2018), "A modified EFQM excellence model for effective evaluation in the hotel industry”, Total Quality Management and Business Excellence, Vol. 29, pp. 1580-1593. 
Mak, B.L.M. (2011), "ISO certification in the tour operator sector", International Journal of Contemporary Hospitality Management, Vol. 23 No. 1, pp. 115-130.

Masi, R. and Cooke, R. (2000), "Effects of transformational leadership on subordinate motivation, empowering norms and organizational productivity", The International Journal of Organizational Analysis, Vol. 8 No. 1, pp. 16-47.

Mendoza, M.I.A., García, R.B.R. and Uribe, P.J.F. (2014), "Liderazgo y su relación con variables de resultado: un modelo estructural comparativo entre liderazgo transformacional y transaccional en una empresa de entretenimiento en méxico", Acta de Investigación Psicológica, Vol. 4, pp. 1412-1429.

Miles, M.B. and Huberman, A.M. (1994), Qualitative Data Analysis. An Expanded Sourcebook, Sage, Thousand Oaks, CA.

Orfila-Sintes, F., Crespí-Cladera, R. and Martínez-Ros, E. (2005), "Innovation activity in the hotel industry: evidence from balearic islands”, Tourism Management, Vol. 26 No. 6, pp. 851-865.

Osseo-Asare, E., Longbottom, D. and Murphy, W.D. (2005), "Leadership best practices for sustaining quality in UK higher education from the perspective of the EFQM excellence model", Quality Assurance in Education, Vol. 13, pp. 148-170.

Pereira-Moliner, J., Claver-Cortés, E., Molina-Azorín, J.F. and Tarí, J.J. (2012), “Quality management environmental management and firm performance: direct and mediating effects in the hotel industry", Journal of Cleaner Production, Vol. 37, pp. 82-92.

Pereira-Moliner, J., Tarí, J.J., Molina-Azorin, J.F. and López-Gamero, M.D. (2016), "The benefits of a quality certificate”, Universia Business Review, No. 50, pp. 106-141.

Pérez, L.H. (1998), "Ventajas y obstáculos en la implantación del modelo europeo Para PYME", Alta Dirección, Vol. 197, pp. 17-23.

Pheng, L.S. and May, C.F. (1997), "Quality management systems: a study of authority and empowerment”, Building Research and Information, Vol. 25 No. 3, pp. 158-169.

Podsakoff, P.M., MacKenzie, S.B., Paine, J.B. and Bachrach, D.G. (2000), "Organizational citizenship behaviors: a critical review of the theoretical and empirical literature and suggestions for future research", Journal of Management, Vol. 26 No. 3, pp. 513-563.

Portela, S. (2016), "El liderazgo transformador en la gestión de la calidad. Un estudio basado en el modelo EFQM", Tesis doctoral, Universidad de Alicante.

Powell, T.C. (1995), "Total quality management as competitive advantage: a review and empirical study”, Strategic Management Journal, Vol. 16 No. 1, pp. 15-37.

Sandbrook, M. (2001), "Using the EFQM excellence model as a framework for improvement and change", Journal of Change Management, Vol. 2 No. 1, pp. 83-90.

Simancas Cruz, J., Garcia Cruz, J.I., Greifemberg, C.A. and Peñarrubia Zaragoa, M.P. (2018), "Strategies to improve the quality and competitiveness of coastal tourism areas: Applying tourism standards", Journal of Tourism Analysis, Vol. 25 No. 1, pp. 68-90.

Soltani, E., Van Der Meer, R. and Williams, T. (2004), "Challenges posed to performance management by TQM gurus. Contributions of individual employees versus systems-level features", Total Quality Management and Business Excellence, Vol. 15 No. 8, pp. 1069-1091.

Sun, H. and Cheng, T.K. (2002), "Comparing reasons, practices and effects of ISO 9000 certification and TQM implementation in norwegian SMEs and large firms", International Small Business Journal: Researching Entrepreneurship, Vol. 20 No. 4, pp. 421-442.

Teoman, S. and Ulengin, F. (2018), "The impact of management leadership on quality performance throughout a supply chain: an empirical study", Total Quality Management and Business Excellence, Vol. 29, pp. 1427-1451.

Turespaña (2015), "Base de datos hoteles de 5 estrellas y 5 estrellas gran lujo", available at: www.spain. info/es/informacion-practica/alojamientos

Model in fivestar hotels 
Waldman, D. (1994), "The contributions of total quality management to a theory of work performance", Academy of Management Review, Vol. 19 No. 3, pp. 510-536.

Wang, C.H., Chen, K.Y. and Chen, S.C. (2012), "Total quality management, market orientation and hotel performance: the moderating effects of external environmental factors", International Journal of Hospitality Management, Vol. 31 No. 1, pp. 119-129.

Yee, W.R., Lee, K.C., Yeung, C.L. and Cheng, T.C. (2013), "The relationships among leadership, goal orientation, and service quality in high-contact service industries: an empirical study", International Journal of Production Economics, Vol. 141 No. 2, pp. 452-464.

Yeung, A., Cheng, E. and Lai, K. (2005), "An empirical model for managing quality in the electronics industry", Production and Operations Management, Vol. 14 No. 2, pp. 189-120.

Yosia, S.R. (2015), "Project manager skills for improving project performance", International Journal of Business Performance Management, Vol. 16

Yukl, G. (1999), "An evaluation of conceptual weaknesses in transformational and charismatic leadership theories", The Leadership Quarterly, Vol. 10 No. 2, pp. 285-305.

$\mathrm{Zu}, \mathrm{X}$., Fredendall, L.D. and Douglas, T.J. (2008), “The evolving theory of quality management: the role of six sigma", Journal of Operations Management, Vol. 26 No. 5, pp. 630-650.

\section{Corresponding author}

Juan José Tarí can be contacted at: jj.tari@ua.es

For instructions on how to order reprints of this article, please visit our website: 